\title{
EDUCATION IN INDUSTRIAL HEALTH
}

\author{
Report of the Education Committee of the Association of Industrial Medical Officers *
}

\section{Introduction}

In 1941 the Association of Industrial Medical Officers prepared a memorandum, 'Training of Industrial Medical Officers', which was published in that year by the British Medical Association as an appendix to its report on industrial health. This memorandum outlined schemes both for war-time and for peace-time. While the principles laid down in the peace-time scheme need little amendment, the Committee proposes to review the problem of education in industrial health more widely, in the light of recent reports on medical education and on the development of industrial medicine. The first report of the Social and Preventive Medicine Committee of the Royal College of Physicians of London (1943) drew attention to the need for education in industrial medicine. The second report of the same Committee (1945), entitled 'Industrial Medicine', went further. It discussed in some detail the need for education of medical officers for industry: for part-time service there would appear to be a need for a short course, lasting perhaps six weeks; for the medical man or woman who wishes to take up industrial health as a career, and whether a special diploma in industrial health is instituted or not, there should be a well-designed course of academic and practical training of one year's duration.

The white paper published by the Ministry of Health on a national health service (1944) makes little mention of occupational medicine, and no mention at all of the need for education in its principles. The Report of an Inter-Departmental Committee on Medical Schools (1944) - the Goodenough report on medical education--makes some mention in a chapter on social medicine of the need for undergraduate training in industrial medicine: during the clinical period the student's training in social medicine should include personal investigations of industrial conditions by visiting the patient's place of employment. In discussing development in post-graduate education the Goodenough report states (p. 219): 'Special provision should be made for instruction in industrial medicine and it is a matter for consideration whether this should form an optional part of the public health course or be organized separately.' While the report refers to the need for organization of post-graduate courses

* Membership of the Committee was as follows: Drs. W. E. Chiesman (Chairman), J. C. Bridge, Donald Hunter, R. E. Lane, T. A. Lloyd Davies, T. Gwynne Maitland, D. C. Norris, C. L. Potts, R. S. F. Schilling, Donald Stewart, and K. M. A. Perry (Secretary). of training for medical practitioners demobilized from the services, it docs not specifically mention industrial medicine as a future opening for some of these practitioners, nor the need for education in it as part of these courses. *

From the brief survey which follows it will be seen that there are considerable opportunities for doctors to become engaged in a whole-time or parttime capacity in one or other of the branches of industrial health service. It is a matter for disappointment that, so far, no plan of any kind for the future development of this service has been evolved by a responsible Government department. The white paper on 'A National Health Service' dismisses industry in a few words. But the Royal College of Physicians of London, in its recent report already mentioned, has done much to emphasize the importance of industrial health and to plan for the future; so it is hoped that its recommendations will be fully considered. If so there should be important developments in this new branch of medicine in the not too distant future. No national health service can be adequate that does not include, as an integral and properly co-ordinated part of the whole, an industrial health service. For this reason adequate facilities for education and training of those doctors, nurses, and others who take part in it, must be provided at the earliest opportunity.

\section{Scope of Industrial Medical Practice}

There is no national industrial medical service in this country. The great majority of large employers and many hundreds of smaller firms have their private medical service. But there is, at the present time, no co-ordination between these services and Government departments concerned with health, or with the hospital and general practitioner service of the country. It should be remembered that "industry' consists, in reality, of all employed persons, not only those, for example, in factories and mines. The number of such 'employed persons' under peace-time conditions is 13 million men and over 4 million women.†

In so far as it has been able to obtain facts $\ddagger$ the

* It is of interest to note that the Nuffield Foundation has announced (April, 1945) that it is prepared to award a limited number of fellowships normally worth $£ 500-£ 800$ a year-to men and women who wish to qualify for teaching and research posts in industrial health. Medical officers in the forces can apply for these fellowships which would become tenable on demobilization.

+ Social Insurance, Part I (1944). H.M.S.O Lond., p. 48 .

* In preparing this report the Committee has had assistance from certain individuals and Government depariments, 
Committee wishes briefly to outline the scope of present-day industrial medical practice in the various branches of British industry.

\section{(a) Factories}

In 1938 the estimated number of factory workers was between 6 and 7 million-a number much increased in war-time. The following is a list of the different branches of industrial medicine engaged one way or another with the health supervision of these men and women.*

(i) Factory Medical Inspectorate. The Factory Department was formerly in the Home Office but in 1940 was transferred to the Ministry of Labour and National Service. It is the oldest Government department dealing with industrial health and comprises general factory inspectors, electrical inspectors, chemical inspectors, engineering inspectors and medical inspectors. It administers those statutory regulations which deal with the many aspects of health and safety in factories, welfare, first aid, notification and investigation of accidents and industrial disease, hours of work, employment of women and young persons, and canteens. At the present time there are ten whole-time medical inspectors of factories who investigate conditions of work with particular reference to occupational diseases, and advise the lay inspectorate on other medical issues which may arise. They are stationed in London, Birmingham, Bristol, Leeds, Liverpool, Manchester, Sheffield and Glasgow.

(ii) Examining Surgeons. Under supervision of the Factory Department some 1750 general practitioners throughout the country give service as examining surgeons under the Factories Act. Their duties consist in medical examination of all young persons under 16 years of age entering factories for employment and those between 16 and 18 employed on certain processes; periodic examination of persons engaged in certain dangerous processes; investigation and reports on cases of industrial disease; and examination and issue of certificates to those persons claiming compensation for scheduled diseases under the Workmen's Compensation Act.

(iii) Factory Medical Officers. Medical officers in factories, whether employed whole or part-time, constitute the main bulk of industrial medical officers. They act as an important link between industry and the general practitioner and hospital services. At the present time there are some 250 whole-time and over 700 part-time doctors working in factories. $\dagger$ The work of these doctors $\ddagger$ varies with the type of industry in which they are employed.

but it must be admitted that because of the many different departments concerned and the lack of a co-ordinating medium of any kind, there has been much difficulty in obtaining data. The Committee therefore presents these figures as being the most accurate available.

figures as being the most accurate available. cerned with certain aspects of health supervision of factory workers.

+ See R.C.P. Report 'Industrial Medicine' (1945), p. 7.

$\dagger$ See R.C.P. Report 'Industrial Medicine’ (1945), p. 7.
$\ddagger$ Medical Supervision in Factories (1944). H.M.S.O. Lond.; see also Report of Committee on Industrial Health Lond.; see also Report of Committee on
in Factories (1941). B.M.A. Lond., p. 9.
Broadly speaking their duties consist of (a) emergency treatment of injuries and sickness at the place of work; (b) end stages in rehabilitation; and (c) the many preventive measures which can be taken within the factory itself against accident, illhealth, or occupational disease. This work offers wide opportunities for research in health and social problems.

(iv) Factory Nurses. At the present time it is estimated that approximately 9000 nurses are employed in factories, 5000 of them being state registered (S.R.N.). These nurses work in the following categories:

(a) assistant nurses working on their own, or under supervision of a nurse (S.R.N.) or doctor;

(b) nurses (S.R.N.) working under a senior nurse who is responsible to a doctor;

(c) nurses (S.R.N.) working in groups but each personally responsible to the doctor;

(d) nurses (S.R.N.) working in factories where there is no medical supervision; and

(e) senior nurses (S.R.N.) responsible to a doctor for groups of nurses in categories $(a)$ and $(b)$.

(b) Mines

A Mines Medical Service is run by the Mines Department of the Ministry of Fuel and Power; it consists of ten whole-time doctors, two at headquarters in London, and eight regional mines medical officers. The number of miners in this country is approximately 750,000 . Much of the work of the regional medical staff is concerned with applications for release from the industry on medical grounds, but it has always been realized that this activity, essential as it is at present, is not their ultimate function.* Medical officers are therefore encouraged to devote as much time as possible to prevention of disease and accidents below ground, to consideration of working environment, and to link up with hospitals, rehabilitation centres, and other institutions to which miners go for treatment. A small number of collieries have, in addition to facilities provided by the state service, their own medical officers, most of them in a parttime capacity. There are 6 whole-time medical officers in this industry appointed by private employers. As far as the Committee can determine the number of women nurses employed by collieries is negligible.

\section{(c) Quarries}

Quarries employ some 75,000 persons and for health and safety purposes come within the scope of the Mines Department; but if a manufacturing process such as the making of tar macadam is carried out in a quarry this falls within the scope of the Factory Department.

\section{(d) Docks}

Docks employ over 106,000 workers and separate medical services for them have been established in

* Brit. J. industr. Med., 1944, 1, 153; ibid., 198. 
Liverpool, Manchester and Glasgow, and one is now being devised for London. These services necessitate the appointment of adequate medical and nursing staff.

\section{(e) Shipbuilding}

Where organized medical services exist in this industry the work of the medical officers is comparable to that of the factory medical officer, shipyards coming under the Factories Act.

\section{(f) Shipping}

The shipping industry employs some 160,000 men - sailors in the Merchant Navy. There are approximately 300 whole-time ship surgeons whose work, if properly carried out, must include them within the ranks of industrial medical officers.* In addition approximately 1000 doctors at any one time, under conditions of peace, are employed as temporary ship surgeons. British ship surgeons, unlike those in certain other countries, are not required to attend courses in maritime hygiene, so here is an immediate field for health training for this industry. It has been suggested that special courses of instruction could well be carried out at the Universities of London, Liverpool, and Glasgow, as the responsibility of a Department of Industrial Health.

\section{(g) Railways. Road Transport}

The number of railway employees at April, 1943, and including the London Passenger Transport Board was 668,145 men and 135,000 women. Doctors employed by railways and road transport are at present mainly concerned with the fitness of applicants for employment and with questions of compensation. This to some extent enables them to see that their workers get appropriate treatment and rehabilitation, but it very considerably limits the scope of such doctors as compared, for example, with that of the factory doctor. Only 16 wholetime doctors are employed by the railways, and 7 whole-time doctors by road transport undertakings.

\section{(h) Other Industries}

The General Post Office employs over half a million workpeople. There is a chief medical officer and 10 medical officers at the G.P.O. Headquarters in London. Their work consists largely of the supervision of sick absence. The junior members of the staff are also concerned with the personal home care of the staff in the London area, i.e. they carry out general practice. $\ddagger$

A few large commercial undertakings and retail stores employ whole- or part-time medical officers.

As far as the Committee can determine there is no medical supervision of agricultural workers, or any organized medical supervision of workers in the building industry. In 1944 there were 778,000

* Brit. J. industr. Med., 1945, 2, 109.

\# The General Post Office is allowed by Parliament to * The General Post Office is allowed by Parliament to contract out of National Health Insurance, and 2600 Post Office medical officers are appointed for this work through-
out the country. The work is that of a panel doctor, and out the country. The work is that
they are naid on a per capita basis. men and 227,000 women engaged as farm workers in the United Kingdom;* and just before the war the number of persons engaged in the building industry on constructional work was a quarter of a million: this figure is likely to increase very considerably in post-war years.

\section{(k) The Silicosis and Asbestosis Medical Board}

This Board consists of a senior medical officer and 10 other whole-time doctors - all with special knowledge of chest diseases - and comprises panels stationed in Sheffield, Swansea, Cardiff, Stoke-onTrent and Manchester. The panels examine and issue certificates of compensation to workers who develop silicosis and asbestosis. Workers on certain processes liable to produce these conditions are periodically examined by members of the Board.

\section{(1) Research Workers in Industrial Health}

Since the last war, the Medical Research Council's Industrial Health Research Board has employed a staff of research workers, many of them nonmedical. $\uparrow$ These workers have largely been separated from hospital, but while this does not greatly matter for statistical, social, or psychological work, it can be a disadvantage where disease is being investigated, as departments such as bacteriology, morbid anatomy, bio-chemistry and radiology have a part to play in these researches. In June, 1943, the Medical Research Council created the Department of Research in Industrial Medicine at the London Hospital. In May, 1944, the Council established at Cambridge a unit for research in applied psychology, and in June, 1945, a unit at Cardiff for research on pneumokoniosis.

The Ministry of Supply experimental station at Porton is concerned primarily with chemical warfare. Many of the problems in this sphere are similar to those of industrial toxicology, and it is well equipped to carry out specific investigations: with a chemical department, a physical department, and a physiological department equipped with animal houses. After the war it seems probable that the ordinary work carried out here will be greatly reduced, and the possibility of industrial problems being studied there is one that needs serious consideration.

That there is urgent need for good research workers to give their attention to problems of industrial health cannot therefore be denied. Some of the problems for future investigation have been recently outlined by the Secretary of the Industrial Health Research Board, $\ddagger$ and it will be for the heads of the new University Departments of Industrial Health both to help find the right men and women and to train them for this work. It must be emphasized, however, that the practising industrial medical officer has much scope for research, and provided his work is properly co-ordinated his * Whitaker's Almanack, 1945, p. 634

$\rightarrow$ The present staff numbers 7 doctors, and 25 physiologists, chemists, physicists, psychologists, statisticians, and gists, chemists, physicists, psychol
technical and laboratory assistants.

\pm Schilling, R. S. F. (1944). Brit. J. industr. Med., 1, 145. 
contribution in this field can become of much importance.

\section{(m) Ministry of National Insurance}

The proposals of the Government concerning workmen's compensation* must lead to the appointment of doctors with knowledge of occupation to deal with 'claims in respect of disablement'; to become 'appointed medical officers' or medical referees; to sit on 'local appeal tribunals' if required; and to act as members of ' medical boards'. In connexion with this last category the Government suggest that 'the Medical Boards of the Ministry of Pensions might be utilized for this purpose.' If this new legislation is to be effective it is vitally necessary that these members of the medical profession should have adequate training in industrial health, for theirs will be a great responsibility.

\section{Present Teaching Facilities}

An inquiry into the extent to which the teaching of industrial health is carried on in the medical schools at the present time revealed that instruction was extremely scanty in London and not much better in the provinces. The table on page 162 gives a summary of the information which was obtained.

Hospitals and Industrial Health. Hospital physicians and surgeons have three distinct functions: the curing of illness, research, and teaching. Training of students, doctors, nurses and almoners (medico-social service workers) must therefore be based to some extent on the teaching hospitals, so their relationship to industry is important.

In regard to the curing of illness the patient's occupational background is the concern of hospitals in the following ways.

(a) Patients disabled by trauma must be given adequate treatment and rehabilitation so that they may return to their old employment; if this is not possible, treatment should not be regarded as finished until training for new employment is completed and found satisfactory. In this connexion hospitals will, in the future, link up closely with the Ministry of Labour, and, through hospital social service or almoners' departments, with individual employers. $\dagger$ Similar guiding principles must also be accepted for patients disabled by ill-health and disease. Patients may frequently have to be advised as to suitable employment; this implies a knowledge of work and work environment on the part of hospital consultants which, at present, is almost non-existent. It is of fundamental importance, therefore, that hospital staffs should be provided with facilities for obtaining information in this direction.

(b) Diagnosis and treatment of occupational

* Social Insurance, Part II: 'Workmen's Compensation' (1944). Cmd.6551. H.M.S.O. Lond., p. 20 et seq.; National Insurance (Industrial Injuries) Bill (1945). H.M.S.O. Lond.; Explanatory Memorandum (on the Bill) by the Minister of National Insurance (1945). Cmd.6651. H.M.S.O. Lond

$t$ Under the Disabled Persons (Employment) Act, 1944, this link has already begun to be established. diseases arising in industry. While the treatment of pneumonia, rheumatism, gastric conditions, or of tuberculosis is of great importance to the individual, the community, and therefore to industry, it must be remembered that there is an ever-present risk of disease being caused directly by occupation. Diseases such as pneumokoniosis, for example, may produce wide problems. Thus there is great opportunity for hospitals to become service departments for industry, particularly in urban areas.

(c) Psychiatric problems commonly arise in industry and specialist advice is often essential. There is ample evidence of the need for collaboration between hospital psychiatrists and industry.*

\section{RECOMMENDATIONS \\ University Departments of Industrial Health}

The Nuffield Foundation has recently endowed a chair of industrial health in the University of Manchester, and Dr. R. E. Lane has been appointed to take up duties as Professor in September, 1945. Readerships in industrial health have also been endowed by the Foundation in the Universities of Durham and Glasgow, but no appointments have so far been made (July 1945). The University of Durham has now decided (May 1945) to implement the Nuffield gift so as to create a chair of industrial health. If the Universities of London, Birmingham, and Liverpool were to follow suit the Committee is of the opinion that the needs of the country in this direction would be adequately covered.

\section{Medical Undergraduate Training.}

Education of medical undergraduates must be directed to making them conscious that a patient has an occupation, that this may have some bearing on the cause of his illness, that the economic results of illness have important repercussions, and that his treatment is not complete until he is again able to earn his living. The undergraduate is not required to become a specialist in occupational health, and only a limited amount of time can be devoted to its study. Much of the instruction can be given during the student's clerkship in the medical and surgical wards. Teachers of medicine and surgery should themselves understand something of the principles of industrial health. The student should also receive a course of at least six lectures on occupational medicine and spend at least three days within the factory when the normal work of the industrial medical officer can be explained to him. He should receive instruction in the departments of accident surgery, social medicine and psychiatry, where they exist, on the relation between these subjects and industry.

\section{Medical Post-graduate Training.}

It is not easy to lay down hard and fast rules for the training of industrial medical officers. It is important that recruits to this sphere should have

* Brit. J. industr. Med., 1945, 2, 41. 
ANNUAL TEACHING IN INDUSTRIAL HEALTH

\begin{tabular}{|c|c|c|c|c|c|c|}
\hline \multicolumn{3}{|c|}{$\begin{array}{l}\text { Hospital } \\
\text { or University }\end{array}$} & Undergraduate & Post-graduate & Nurses * & Almoners \\
\hline \multicolumn{3}{|c|}{ London Hospitals } & Fracture clinic. & & & \\
\hline \multicolumn{2}{|c|}{$\begin{array}{l}\text { Charing Cross } \\
\text { Guy's }\end{array}$} & $\cdots$ & $\begin{array}{l}\text { Lectures in public health } \\
\text { course. }\end{array}$ & & Lectures. & \\
\hline \multirow{4}{*}{\multicolumn{3}{|c|}{$\begin{array}{l}\text { London } \\
\text { Royal Free ... } \\
\text { Middlesex ... } \\
\text { St. Bartholomew's }\end{array}$}} & $\begin{array}{l}\text { Lectures and visit to } \\
\text { factory. }\end{array}$ & & & \\
\hline & & & $\begin{array}{l}9 \text { lectures. } \\
\text { Nil. }\end{array}$ & & & \\
\hline & & & Nil. & & & \\
\hline & & & $\begin{array}{l}\text { As part of course of } 20 \\
\text { lectures in state medicine. }\end{array}$ & & & \\
\hline \multicolumn{2}{|c|}{ St. George's } & $\begin{array}{l}\cdots \\
\cdots\end{array}$ & $\begin{array}{l}2 \text { lectures. } \\
\text { Nil. }\end{array}$ & & & \\
\hline \multicolumn{2}{|c|}{ St. Thomas's } & $\cdots$ & $\begin{array}{l}\text { Lectures from time to time } \\
\text { by industrial medical } \\
\text { officers. }\end{array}$ & & & \\
\hline \multicolumn{3}{|c|}{ University College } & $\begin{array}{l}\text { Lectures in course on } \\
\text { social medicine. }\end{array}$ & & & $\begin{array}{l}\text { Attend lectures in } \\
\text { social medicine } \\
\text { course. }\end{array}$ \\
\hline \multicolumn{2}{|l|}{ Westminster } & . & $\begin{array}{l}6 \text { lectures; visits to fac- } \\
\text { tories. }\end{array}$ & & & \\
\hline \multicolumn{2}{|c|}{ West London } & $\because$ & Nil. & & & \\
\hline \multicolumn{2}{|c|}{$\begin{array}{l}\text { London School } \\
\text { Hygiene. }\end{array}$} & of & Nil. & $\begin{array}{l}20 \text { lectures in D.P.H. } \\
\text { course. } \dagger\end{array}$ & & \\
\hline \multicolumn{2}{|c|}{ Birmingham .. } & $\cdots$ & Nil. & $\begin{array}{l}\text { Course of } 6 \text { lectures } 3 \\
\text { times a year. }\end{array}$ & $\begin{array}{l}\text { (a) } 1 \text { year's } \\
\text { course. } \\
\text { (b) } 3 \text { one-day } \\
\text { courses. }\end{array}$ & \\
\hline Bristol .. & $\cdots$ & $\cdots$ & 2 lectures. & 2 week-end courses. & $\begin{array}{l}1 \text { week-end. } \\
13 \text { months' } \\
\text { course. }\end{array}$ & \\
\hline Cambridge & $\cdots$ & $\cdots$ & Nil. & & & \\
\hline Durham & $\cdots$ & $\cdots$ & Nil. & & 1-day courses & \\
\hline Leeds .. & $\cdots$ & $\cdots$ & Nil. & $\begin{array}{l}\text { 1-day. } \\
\text { Occasional week-end } \\
\text { course. }\end{array}$ & $\begin{array}{l}\text { with College } \\
\text { of Nursing. }\end{array}$ & \\
\hline $\begin{array}{l}\text { Liverpool } \\
\text { Manchester }\end{array}$ & $\begin{array}{l}\cdots \\
\cdots\end{array}$ & $\begin{array}{l}\cdots \\
\cdots\end{array}$ & $\begin{array}{l}\text { Nil. } \\
6 \text { lectures; dresserships in }\end{array}$ & (a) Course of 6 lectures & Three 1-day & 1 week-end. \\
\hline & & & factories. & $\begin{array}{l}3 \text { times a year. } \\
(b) 6 \text { lectures in } \\
\text { occupational health } \\
(\text { D.P.H. course). } \dagger\end{array}$ & courses. & \\
\hline $\begin{array}{l}\text { Oxford } \\
\text { Sheffeld }\end{array}$ & $\cdots$ & . & Nil. & & & \\
\hline snemerd & $\cdots$ & $\cdots$ & Lectures. & $\begin{array}{l}2 \text { week-end courses; } \\
\text { visits to factories. }\end{array}$ & & \\
\hline Wales .. & $\cdots$ & $\cdots$ & $\begin{array}{l}2 \text { lectures; } 1 \text { visit to } \\
\text { factory. }\end{array}$ & D.P.H. course. $\dagger$ & & \\
\hline Aberdeen & $\cdots$ & $\cdots$ & $\begin{array}{l}8 \text { lectures in public health } \\
\text { course. }\end{array}$ & $\begin{array}{l}7 \text { lectures in D.P.H. } \\
\text { course. } \dagger\end{array}$ & & \\
\hline Edinburgh & . & . & $\begin{array}{l}2 \text { lectures; visits to fac- } \\
\text { tories. }\end{array}$ & $\begin{array}{l}6 \text { lectures in D.P.H. } \\
\text { course. } \dagger\end{array}$ & & $\begin{array}{l}\text { Attend lectures in } \\
\text { D.P.H. course. } \dagger\end{array}$ \\
\hline Glasgow & . & . & 3 lectures. & 9 lectures. & $\begin{array}{l}3 \text { months' } \\
\text { course with } \\
\text { College of } \\
\text { Nursing. }\end{array}$ & \\
\hline St. Andrew’s & . & $\cdots$ & 3 lectures. & $\begin{array}{c}10 \text { lectures in D.P.H. } \\
\text { course. } \dagger\end{array}$ & & \\
\hline
\end{tabular}

* For account of courses held by the Royal College of Nursing, see Brit. J. industr. Med., 1944, 1, 89. The University of London, for its Diploma in Nursing, allows 'Industrial Nursing, to be taken under Part B, subject to certain regulations. (See same reference.)
+ Suspended during the war.

had a sound medical training and be good clinicians, and that they should, after qualifying, have had at least two years in which to gain clinical experience both in house appointments and in general practice. It then becomes necessary to offer three distinct types of training:

(i) For the man who is to devote his life to this type of work and who intends to become a consultant in it.*

(ii) For the man who intends to become an industrial medical officer, whether parttime or whole-time.

(iii) For special appointments. 
(i) For the Prospective Consultant. For the prospective consultant a special type of training should be available. These men should hold studentships or fellowships in University Departments of Industrial Health where they should spend at least one year; they should have ample opportunity of seeing numerous industries and working in a factory for at least one year; they should also be enabled to meet men connected with various aspects of industrial activity-not necessarily medical. They would, during the tenure of their appointment, be occupied in field research, in travel and in certain types of teaching. Such men should have obtained the M.R.C.P.

(ii) For the Whole-time Industrial Medical Officer. The whole-time industrial medical officer should, if possible, devote three months to his training. It is realized, however, that there are many experienced and valuable men who could only take such a course if it were arranged on a part-time basis. So it seems essential that some educational facilities should be provided by all universities with a medical faculty. Refresher courses are of much importance, and form a fundamental part of any teaching programme. Part of the course would be of a practical nature and include visits to a wide range of industries, short periods spent in industrial medical departments, and sessions in both eye and skin hospital clinics.

A suggested outline of the points to be covered in a course for industrial medical officers is given as an appendix.

(iii) (a) For Examining Surgeons. Examining surgeons under the Factories Act are appointed to-day without any special training for their work because of the lack of facilities. The first essential for these doctors is a knowledge of general medicine, but this knowledge can only be put to its fullest use in industry by special training in the principles of job allocation, industrial toxicology, and workmen's compensation. Special courses are therefore necessary to supply this knowledge. These courses should last for two weeks and be given perhaps twice a year in a suitably placed University Department of Industrial Health. These courses would also be ' refresher' courses, and examining surgeons already holding appointments would be well advised to attend them. This would be more likely if they were subsidized. Courses of this type would be comparable to those sponsored by the Ministry of Health for general practitioners.

The examining surgeon's course would deal with legal aspects of the work, industrial diseases and their early detection, and care of juveniles. Visits to factories would be arranged and their attendance at a good skin clinic insisted upon.

It is quite possible that in the future development of industrial medicine the examining surgeon may be given greater responsibility. If such a development occurs, more emphasis must be placed upon the training of these men for their work; satisfactory instruction would best be afforded by the ordinary course outlined in the appendix. (b) For Factory Medical Inspectors. In future factory medical inspectors should at least have had the full course of the industrial medical officer. Better still, they should have held a studentship or fellowship at a University Department of Industrial Health. Such a training would be an excellent preparation for the work. The question arises, however, as to whether the salary and conditions offered at present by the Factory Department would attract men who had such a prolonged training. Under present conditions this is doubtful.

\section{Training of Nurses}

The education of nurses is of much importance in any industrial health plan. They are key workers in the service. More emphasis should be laid on the need for experienced industrial medical officers to take part in their training, and for it to become an important responsibility of University Departments of Industrial Health. The syllabus for such a course might well be based on that set out in detail in a recent article by Dr. A. J. Amor and Miss Clare Sykes.* In obtaining recruits for courses so far held in this country there has been no difficulty, because of the great increase in the number of nurses employed. The Royal College of Nursing has been the pioneer in this direction, and a tribute must be paid to their work in this field. The College has granted its own Certificate in Industrial Nursing since 1935.

A three months' whole-time course would be ideal, but would raise financial difficulties for many nurses, and with the present-day shortage of nurses is probably impractical.

In Birmingham the nurses work for a year at the Birmingham Accident Hospital as staff nurses and are trained in industrial subjects, the University granting a Certificate in Industrial Nursing after examination. Nurses already holding industrial appointments and nominated by their medical officer are also accepted for training.

Similar courses of training could well be arranged at other university centres, but it is desirable that there should be only one Certificate in the subject, granted by some central body representative both of nurses and industrial medical officers.

It might also be possible to offer part-time industrial training to staff nurses holding casualty or other appointments in any hospital in an industrial area. Part-time training along these lines would probably occupy 9-12 months. Experience shows that it is of the utmost importance to attract girls of a good general education to this branch of work. Those who have not this background find themselves incapable of taking advantage of the instruction given, and fail to make good industrial nurses.

\section{Education of the Layman}

Non-medical Personnel in Industry. In every factory, large or small, the works manager, technicians, foremen, and the workers themselves, and 
particularly the personnel officer, all play some part in maintaining the health of the workers and preventing accident and disease. There is therefore a need for general education on health matters and this should be supplied by a University Department of Industrial Health. Manchester University has done this successfully for the past few years.

Hospital Personnel. It is to be hoped that eventually all teaching hospitals will have on their staff, or available to them, a good industrial medical officer to do some teaching on industrial medical subjects--just as at present many teaching hospitals have a general practitioner to give one or two lectures on the special nature of his work. Such a man could best undertake undergraduate teaching along the lines suggested in the Interim Report (1943) of the Social and Preventive Medicine Committee of the Royal College of Physicians. Detailed instruction on occupational diseases need not be given, but teaching would aim at providing knowledge and understanding of health and social problems relating both to industrial workers themselves, and to their environment. It would be a good thing if one senior member of the medical staff took a particular interest in the problems of occupational disease, just as the orthopaedic or accident department takes an interest in industrial injuries and their rehabilitation for local industry.

Almoner or Social Service Worker. The almoner is a most important link between the hospital and industry. She should have a much wider training in industrial subjects; at present these are dealt with only in their very broadest aspects in her original training. The practical training of the almoner in her own particular hospital, with its special industrial contacts, should be the responsibility of some specially appointed doctor with experience of i.ciustry, preferably a whole-time local industrial medical officer.

\section{Diploma in Industrial Health}

Although there are many arguments against an increase in the number of diplomas issued following study and examination in special subjects, from the trend of events in the establishment of a national health service, including a consultant service, it would appear that if industrial health is to be recognized as a special branch of medicine then a Diploma in Industrial Health will become a necessity.

A special committee of the General Medical Council on the registration of specialists has decided that it is desirable to have a register of specialists. They say that such a register will have to be available at the start of the national health service. The criteria for inclusion on such a register will initially depend on the fact that a man had acted as a specialist in the past and was generally recognized as a specialist by other practitioners in the area where he practised. Subsequently, the inclusion of specialists will depend on post-graduate qualifications and experience in the specialty con- cerned. The fact that a doctor had a Diploma in Industrial Health might assist employers and others in making appointments to posts.

This Committee holds the view that special medical diplomas have only a limited use. A diploma is not an inspiring stimulus to or an end of higher medical studies. The function of a postgraduate school of medicine is to provide opportunity for research and the training of specialists, and if such training is entirely centred on the acquisition of a diploma, the broader aspects tend to be excluded to the detriment both of the school and the graduate. It is important to recognize that, so far, the value of special medical diplomas has been small, except in the case of public health The criterion for specialist or consultant in the teaching hospitals, and in many of the large provincial non-teaching hospitals, is experience plus the possession of either the M.R.C.P. or F.R.C.S. It is rare to find a consultant on the staff of a large hospital with a diploma in his specialty in addition to these qualifications, except perhaps in those branches of medicine which may be considered as ancillary or non-clinical, such as radiology or anaesthetics. Fundamentally those practising industrial health must have a sound clinical background. Factory experience and special lectures will be required during the introductory period for any new industrial medical officer. The possession of the M.D. or M.R.C.P. will always be desirable, even with a Diploma in Industrial Health. One useful addition to the examination for the M.D. and the M.R.C.P. might be the possibility of taking a special subject as an integral part of the examination, as occurs at certain Scottish universities and the Royal College of Physicians of Edinburgh, the special subject in this instance being industrial health.

Despite these criticisms of the principles of medical diplomas - with the exception of the D.P.H., the value of which is fully recognized-the Committee is of the opinion that the creation of a Diploma in Industrial Health is necessary in the immediate development of this new branch of medicine.

The Goodenough report (p. 231) recommendsagain with the notable exception of the D.P.H. that special diplomas should be given by the Royal Medical Colleges; thus satisfactory machinery could be set up to equate standards. The Committee agrees with this, and recommends that if a Diploma in Industrial Health is instituted it should be given by the Royal Colleges who would become the body responsible both for standards and examination. It would not be in the best interests of industrial medicine if diplomas in the subject were instituted by separate universities or other bodies throughout the country.

Dr. J. C. Bridge advocates that, if a Diploma is instituted, it should be a registrable qualification ; in this case standards would be equated by the General Council of Medical Education and Registration, and any examining body would be free to institute its own Diploma. 


\section{Summary}

1. From a survey of present industrial medical practice in different industries it can reasonably be concluded that there will be a continued demand for doctors and nurses in this field. Plans for education in industrial health must therefore be made at the earliest opportunity.

2. Present facilities for education in industrial health are quite inadequate; but with appointments of Professors and Readers in the Universities of Manchester, Durham and Glasgow now materializing there is good prospect of early improvement. Further appointments should be made at London, Birmingham and Liverpool Universities.

3. Medical undergraduate training in the principles of industrial health should be carried out in every medical school.

4. Medical post-graduate training should be available at universities in industrial areas for potential consultants in the field, for both whole-time and part-time industrial medical officers, for examining surgeons, and for medical inspectors of factories. Training should be by means of fellowships at University Departments of Industrial Health, whole-time courses of study, part-time courses, and refresher courses.

5. Training of nurses for industry is an important function of University Departments of Industrial Health. But one central body, representative both of nurses and industrial medical officers, should lay down standards of training and carry out examinations for the Certificate in Industrial Nursing.

6. There is need for education of laymen in industrial health, particularly for almoners or social service workers at hospitals and for other hospital personnel.

7. Although there are many arguments against an increase in the number of medical diplomas issued after a term of post-graduate study, it appears that a Diploma in Industrial Health has now become a necessity. The Diploma should be instituted solely by the Royal Colleges who would become the body responsible for standards and examination.

\section{Acknowledgments}

The Committee acknowledges with thanks information given by Dr. A. J. Amor, Ministry of Supply; Dr. T. Bedford, Industrial Health Research Board: Dr. S. W. Fisher, Ministry of Fuel and Power; Professor J. M. Mackintosh, London School of Hygiene: Dr. E. R. A. Merewether, Factory Department, Ministry of Labour and National Service; Dr. Alan Moncrieff; the late Dr. W. L. Scott, General Post Office; and Deans of various medical schools in London, the provinces, and Scotland.

\section{APPENDIX}

Outline of points to be covered in a Course for Industrial A. Introductory Medical Officers

1. The structure of industry.

2. Development of health legislation and medical services in industry.

3. Functions of labour management, personnel and welfare services

4. Trade Unions, industrial relations, wage agreements, joint production councils, etc.

5. Functions of an industrial health service and its relation to general practitioners, consultant and other health services.
R. General Principles of Social and Preventive Medicine

1. Infection.

2. Nutrition.

3. Environment.

4. Heredity.

5. Medical statistics.

6. Group sickness incidence and labour wastage in industry.

7. Planning of controlled investigations.

\section{Organization of a Health Service in Industry}

1. Relation to other managerial departments and workpeople within the industry.

2. Accommodation and equipment.

3. Staffing, including nursing staff.

4. Ancillary services, i.e. dental, ophthalmic, or chiropody.

5. Casualty service.

6. A.dministration.

7. Records.

\section{Placement of Workers}

1. The pre-placement medical examination.

2. Principles of vocational guidance and selection, the use and limitations of aptitude and intelligence tests.

3. Job analysis in relation to capacity for work.

4. Reinstatement on return to work after illness or injury.

\section{E. Physiology and Psychology of Work}

Muscular work, lifting, static strain, fatigue, and recovery: hours of work, rest-pauses, speed of work, night work, shift systems: physiological aspects of machine design, seating and arrangement of benches: monotony, boredom and incentives; health aspects of time and motion study.

\section{F. Working Environment}

1. Heating and ventilation.

2. Atmospheric pollution and its control.

3. Lighting.

4. Occupational causes of physical disability and their prevention.

5. Sanitation. Washing and sanitary accommodation; facilities for accommodating and drying clothes; general cleanliness; overcrowding; drainage of floors, etc.

\section{G. Industrial Accidents}
1. Causes.
2. Statistics.
3. Prevention.
4. Treatment.

\section{H. Occupational Diseases}

Etiology, prevention and treatment.

\section{J. Rehabilitation and Resettlement in Industry}

1. Rehabilitation of sick and injured workmen.

2 . Resettlement and retraining.

3. Legislation.

\section{K. Special Problems related to Employment of Women and Young Persons}

\section{Industrial Health Legislation}

Factories Act, Mines and Quarries Act, Social Insurance, Disabled Persons (Employment) Act, etc. 